\title{
Insight into the role of cyanobacterial bloom in the trophic link between ciliates and predatory copepods
}

\author{
Joanna Kosiba $\mathbb{1}$ - Wojciech Krztoń
}

Received: 28 June 2021/Revised: 30 November 2021/Accepted: 30 November 2021 / Published online: 15 December 2021

(C) The Author(s) 2021

\begin{abstract}
An important group of protozooplankton, the ciliates, are a crucial component of aquatic food webs. They are the main grazers on bacteria and algae transferring carbon to higher levels of the food web (metazooplankton and fish fry). Changes in the quality and quantity of protozooplankton can modify the quality and quantity of metazooplankton, especially predatory copepods, causing changes in energy transfer and the matter cycle. Observable climate change is one of the most significant factors promoting the increase of cyanobacterial blooms. Therefore, the aim of this study was to find out how cyanobacterial blooms modify relationships between ciliates (prey) and copepods (predator), and to discover possible pathways of changes in freshwater food webs. We analysed the relationship between the biomass of predatory copepods and feeding guilds of ciliates (algivorous, bacterivorous, bacteri-algivorous). The relationship of predators biomass with algivorous and bacteri-algivorous ciliate biomasses, with a simultaneous lack of relationship with bacterivorous ciliate biomass, demonstrates that bacterial fixed carbon may be only partially contributing to the total energy
\end{abstract}

Handling Editor: Eric R. Larson

J. Kosiba $(\bowtie) \cdot$ W. Krztoń

Institute of Nature Conservation, Polish Academy of

Sciences, al. Adama Mickiewicza 33, 31-120 Kraków,

Poland

e-mail: kosiba@iop.krakow.pl passed through this link. Results demonstrated that the bloom enhanced the relationship between prey and predator. Larger and free-swimming ciliate species appear to play a greater role in energy transfer than smaller sedentary species.

Keywords Ciliates $\cdot$ Predatory copepods $\cdot$ Feeding guilds $\cdot$ Cyanobacterial blooms $\cdot$ Shallow freshwaters

\section{Introduction}

Zooplankton species, both proto- and metazooplankton, are directly or indirectly dependent on primary producers (Pace \& Lovett, 2013), which in all waterbodies are phytoplankton. One particular group included by ecologists as phytoplankton are cyanobacteria. Many species of cyanobacteria are capable of releasing cyanotoxins which can negatively affect other organisms or become concentrated via bioaccumulation, thus threatening not only aquatic but also terrestrial organisms (Papadimitriou et al., 2010; Martins et al., 2011; Paldavičiené et al., 2015). Apart from toxins, cyanobacteria are capable of secreting other harmful metabolites (e.g. Codd, 1995; Chorus, 2001; Puharinen, 2021). Additionally, it is believed that due to their low content of polyunsaturated fatty acids (PUFA) cyanobacteria are not a good food source for zooplankton (Elert et al., 2003; Wilson 
et al., 2006), although they do in fact produce amino acids, and also contain large amounts of proteins, carbohydrates, lipids, minerals, vitamins and pigments (Pagels et al., 2021). Therefore, from the other hand, they might also be an attractive food for zooplankton (Wilk-Woźniak, 2020). However, it can ultimately be seen that one of the negative effects of cyanobacterial blooms is a decrease in biodiversity of water ecosystems, including in particular the zooplankton group (Kosiba et al., 2018) and changes in their functional groups (Krztoń et al., 2019; Krztoń \& Kosiba, 2020).

For many years, studies of primary producerconsumer relationships in aquatic ecosystems were conducted on an incomplete set which included two elements: phytoplankton (primary producers) and metazooplankton (primary consumers). It was only in the late 1980s and early 1990s that the "microbial loop" was discovered (e.g. Jumars et al., 1989; Weisse et al., 1990) - protozooplankton, including ciliates, were recognized as an important component of the food web (Christoffersen et al., 1990; Kalinowska, 2004; Zingel et al., 2007). However, due to difficulties in identifying ciliates, studies on this group are still in a pioneering phase and are being conducted by only a few research groups (Sherr \& Sherr, 2002; Agasild et al., 2013; Boas et al., 2020; Napiórkowska-Krzebietke et al., 2021), although the results obtained are important for understanding the changes taking place in aquatic ecosystems, which are particularly sensitive ecosystems which react quickly to climate change (Firth \& Fisher, 2012). One of the significant changes predicted as a result of global warming is the proliferation of toxic species of cyanobacteria, more frequent and longer-lasting blooms, with increased toxicity (Paerl \& Huisman, 2009), especially in aquatic ecosystems of continental and boreal climate zones (Mantzouki et al., 2018). Therefore, studies of the mutual relationships amongst basic elements of the food webs of aquatic ecosystems will allow us to indicate what changes are generated by cyanobacterial blooms and how aquatic ecosystems may, in the future, react to climate changes.

Protozooplankton is a crucial component that transfers carbon to higher levels of food webs (Sherr \& Sherr, 2002; Sommer et al., 2012; Agasild et al., 2013; Kosiba et al., 2017). An important group of protozooplankton, the ciliates (phylum Ciliophora; Warren et al., 2016), consists of species that are involved in the complex of interactions contributing substantially to carbon and nutrient turnover and the diet of primary consumers (Sherr \& Sherr, 2007). Ciliates are one of the important part of the Harmful Algal Blooms "micronet" (Wilk-Woźniak, 2020), which might elongate the trophic chain in carbon and nutrient transfer. The ciliates are main grazers on bacteria, unicellular algae, filamentous cyanobacteria, and they may also be important in the transformation of ultrafine organic matter into a particle size range more available to metazooplankton (Porter et al., 1979). They are good food for predatory metazooplankton (Sanders \& Wickham, 1993). However, the impact of predation on ciliates has been underestimated because most ciliates have soft bodies and this material is difficult to detect in the gut contents of their potential predators (Jack \& Gilbert, 1997). Amongst metazooplankton, predatory copepods are an important group, since large-bodied predatory copepods can effectively consume ciliates (Laybourn-Parry et al., 1988; Kalinowska et al., 2015). Copepod predation on ciliates is well documented in studies of marine systems (e.g. Calbet \& Saiz, 2005) but not many studies exist for freshwaters. For the most part, the simple trophic relationship between ciliates and predatory metazooplankton has been studied (Porter et al., 1979; Archbold \& Berger, 1985). Eutrophic shallow lakes can be suitable for studying trophic interactions between predatory copepods and ciliates because of the dominance of a few species which replace each other during the seasonal cycle in waterbodies (Jeppesen et al., 1997; Jürgens et al., 1999). Copepods are also important because they are the main food source for fish fry, high amounts of these metazooplankton organisms are vital for fish in their period of infancy (Güher, 2002).

Changes in the quality and quantity of protozooplankton can modify the quality and quantity of metazooplankton, and especially copepods, causing changes in energy transfer and the matter cycle. Therefore, the aim of this study was to find out how cyanobacterial blooms modify the relationships between ciliates and copepods (predators). Here we explore the relationships between planktonic predators and their prey in order to determine the contribution of three different feeding guilds of ciliates in energy transfer in the aquatic food web, in non-bloom and bloom circumstances. We define feeding guilds consistent with Stroud et al. (2015): "A group of species that exploit the same class of resources in a similar 
way. Guilds are a specialized kind of functional group centred on resource use and its associated processes".

We tested the following hypotheses: Hypothesis 1 The biomass of predatory copepods is significantly correlated with the biomass of ciliates during periods of bloom because during cyanobacterial blooms carbon transfer takes place from the bacteria via the ciliates to the predatory zooplankton. Hypothesis 2 During cyanobacterial blooms the biomass of bacterivorous ciliates and bacteri-algivorous ciliates is significantly higher than in non-bloom periods, but the biomass of algivorous ciliates is significantly lower than during non-bloom periods. Hypothesis 3 There will be an effect of the biomass of individual guilds of ciliates on the predatory copepods.

Here we expect that during bloom periods, the biomass of bacterivorous ciliates will have a significant effect on the biomass of predatory copepods. On the other hand, the biomass of algivorous ciliates will not have a significant effect on the biomass of predatory copepods during bloom periods, but will have a significant effect during non-bloom periods. We also expect that the biomass of mixed-feeding bacteri-algivorous ciliates will have a significant effect on the biomass of predatory copepods in both periods.

\section{Materials and methods}

Study area and sampling procedure

The study was conducted in four, northern temperate waterbodies in Southern Poland (Kraków) (Table 1). Two of them are natural oxbow lakes (Tyniec 1, T1; Tyniec 2, T2) formed by the Vistula River, and the further two are artificial ponds (Podkamycze 1, P1; Podkamycze 2, P2). All the studied waterbodies are relatively small, covering $5.75-17.28$ ha with a maximum depth from 1.9 to $3.0 \mathrm{~m}$ (Table 1). They are all classified as eutrophic according to Carlson \& Simpson (1996) and are near each other, so the weather conditions are similar and do not affect the possible differences of functioning of the waterbodies. All of these waterbodies are prone to cyanobacterial blooms, defined as visible discolouration of water (Huisman et al., 2018), and cyanobacteria biomass exceeded $3 \mathrm{mg} / \mathrm{l}$ (Nebaeus, 1984). Samples were collected during the period May-October, in 2014 and 2017, every other week, covering periods before cyanobacterial blooms and during the blooms. Samples were collected from the central point of each waterbody, at a depth of $1 \mathrm{~m}$. In total, 101 sample sets were collected for biological analyses: phytoplankton with cyanobacteria, protozooplankton (ciliates) and metazooplankton (rotifers, cladocerans, copepods) but for further analysis only the group of predatory copepods was used. Basic physical and chemical parameters (max. depth, water temperature, $\mathrm{pH}$, conductivity, oxygen saturation and concentration of chlorophyll $a$ ) of the studied waterbodies were measured in situ with a YSI 6600 V2 Multiparameter Probe.

Samples for phytoplankton, ciliates and metazooplankton were taken separately. The samples were taken using a 5-1 Ruttner sampler from a volume of 101 of water and were concentrated with a planktonic net $(10 \mu \mathrm{m}$ for cyanobacteria and ciliates and $50 \mu \mathrm{m}$ for metazooplankton). The samples for quantitative analyses were fixed (Lugol's solution for phytoplankton and ciliates, and 4\% formaldehyde for metazooplankton). Phytoplankton, excluding of cyanobacteria, were identified with the use of the keys listed in WilkWoźniak (2009), and counted in a modified chamber $(0.15 \mathrm{ml})$. Cyanobacteria were identified using the keys: Komárek \& Anagnostidis (1998), Komárek \& Anagnostidis (2005), Komárek (2013). Phytoplankton biomass was calculated as a biovolume by comparing specimens with their geometrical shapes according to Rott (1981). The ciliates were identified in $1 \mathrm{ml}$ chambers with glass covers according to Foissner \& Berger $(1996,1999)$ and the total biomass of ciliates (mg/l) was calculated according to Putt \& Stoecker (1989), Jerome et al. (1993), Wiąckowski et al. (1994a). The averages of three counts were calculated. Metazooplankton samples were analysed in $0.5 \mathrm{ml}$ chambers. The averages of five repetitions were counted. Species were identified according to Ejsmont-Karabin et al. (2004) and Błędzki \& Rybak (2016). Dry weight was calculated using a regression equation defining the body length and weight for each species (Cummins et al., 1969; Dumont et al., 1975; Ruttner-Kolisko, 1977; Pearsson \& Ekbohm, 1980). Because phytoplankton and protozooplankton were calculated as fresh biomass, metazooplankton dry mass was recalculated according to the index proposed by Bottrell et al. (1976). All microscopy analysis of phytoplankton, ciliates and metazooplankton 
Table 1 Basic information about the studied waterbodies

\begin{tabular}{|c|c|c|c|c|}
\hline & PODKAMYCZE 1 & PODKAMYCZE 2 & TYNIEC 1 & TYNIEC 2 \\
\hline $\begin{array}{r}\text { Geographical } \\
\text { coordinates }\end{array}$ & $\begin{array}{l}50^{\circ} 05^{\prime} 11^{\prime \prime} \mathrm{N}, 19^{\circ} 50^{\prime} 01.6^{\prime \prime} \\
\mathrm{E}\end{array}$ & $\begin{array}{l}50^{\circ} 04^{\prime} 59.6^{\prime \prime} \mathrm{N}, 19^{\circ} 50^{\prime} \\
05.4^{\prime \prime} \mathrm{E}\end{array}$ & $\begin{array}{l}50^{\circ} 01^{\prime} 47^{\prime \prime} \mathrm{N}, 19^{\circ} 49^{\prime} \\
39.8^{\prime \prime} \mathrm{E}\end{array}$ & $\begin{array}{l}50^{\circ} 01^{\prime} 28.1^{\prime \prime} \mathrm{N} 19^{\circ} \\
48^{\prime} 47.7^{\prime \prime} \mathrm{E}\end{array}$ \\
\hline Type of waterbody & Artificial & Artificial & Natural & Natural \\
\hline Trophic class & Eutrophic & Eutrophic & Eutrophic & Eutrophic \\
\hline Max depth (m) & $3.0 \mathrm{~m}$ & $2.5 \mathrm{~m}$ & $3.0 \mathrm{~m}$ & $1.9 \mathrm{~m}$ \\
\hline Area (ha) & 16.82 ha & 17.28 ha & 5.75 ha & 8.61 ha \\
\hline $\begin{array}{l}\text { Period with } \\
\text { cyanobacterial } \\
\text { bloom } \\
\text { (cyanobacteria } \\
\text { biomass } \geq 3 \mathrm{mg} \text { / } \\
\text { 1) }\end{array}$ & $\begin{array}{l}\text { 2014: July } \\
\text { 2017: from August to } \\
\text { September }\end{array}$ & $\begin{array}{l}\text { 2014: from June to October } \\
\text { 2017: from July to October }\end{array}$ & $\begin{array}{l}\text { 2014: from August to } \\
\text { October } \\
\text { 2017: from September to } \\
\text { October }\end{array}$ & $\begin{array}{l}\text { 2017: from July to } \\
\text { October }\end{array}$ \\
\hline $\begin{array}{l}\text { Mean cyanobacteria } \\
\text { biomass }[\mathrm{mg} / \mathrm{l}] \text { in } \\
\text { all samples }\end{array}$ & 1.20 & 29.27 & 3.19 & 8.53 \\
\hline $\begin{array}{l}\text { Max cyanobacteria } \\
\text { biomass }[\mathrm{mg} / \mathrm{l}] \text { in } \\
\text { all samples }\end{array}$ & 9.47 & 419.18 & 12.83 & 30.14 \\
\hline $\begin{array}{l}\text { Species of } \\
\text { cyanobacteria } \\
\text { present in studied } \\
\text { waterbodies }\end{array}$ & $\begin{array}{l}\text { 2014: Aphanizomenon } \\
\text { flosaquae (Ralfs ex } \\
\text { Bornet \& Flahault, 1886) } \\
\text { with Microcystis } \\
\text { aeruginosa (Kützing) } \\
\text { Kützing, } 1846 \text { and } \\
\text { Dolichospermum sp. } \\
\text { 2017: Aphanizomenon } \\
\text { flosaquae, } \\
\text { Dolichospermum } \\
\text { flosaquae (Brébisson ex } \\
\text { Bornet \& Flahault) } \\
\text { P.Wacklin, L.Hoffmann } \\
\text { \& J.Komárek, 2009, } \\
\text { Microcystis aeruginosa, } \\
\text { Microcystis viridis } \\
\text { (A.Braun) Lemmermann, } \\
\text { 1903, Microcystis sp., } \\
\text { Gomphosphaeria } \text { sp. }\end{array}$ & $\begin{array}{l}\text { 2014: Aphanizomenon } \\
\text { flosaquae with } \\
\text { Microcystis aeruginosa } \\
\text { 2017: Microcystis } \\
\text { aeruginosa, Microcystis } \\
\text { wesenbergii (Komárek) } \\
\text { Komárek ex Komárek } \\
\text { 2006, Woronichinia } \\
\text { naegeliana (Unger) } \\
\text { Elenkin 1933, } \\
\text { Gomphosphaeria sp., } \\
\text { Aphanizomenon } \\
\text { flosaquae, Snowella sp., } \\
\text { Gleocapsa } \text { sp., } \\
\text { Merismopedia tenuissima } \\
\text { Lemmermann, 1898, } \\
\text { Aphanocapsa } \text { sp., } \\
\text { Oscillatoria sp., }\end{array}$ & $\begin{array}{l}\text { 2014: Aphanocapsa sp., } \\
\text { Microcystis ichthyoblabe } \\
\text { (G.Kunze) Kützing, } \\
\text { 1843, Microcystis } \\
\text { wesenbergii, } \\
\text { Woronichinia } \\
\text { naegeliana, } \\
\text { Aphanizomenon } \\
\text { flosaquae, Microcystis } \\
\text { aeruginosa, Phormidium } \\
\text { sp. } \\
\text { 2017: Microcystis } \\
\text { aeruginosa, } \\
\text { Microcystis wesenbergii, } \\
\text { Microcystis } \text { sp., Snowella } \\
\text { sp., Snowella lacustris } \\
\text { (Chodat) Komárek \& } \\
\text { Hindák, 1988, } \\
\text { Aphanizomenon sp., } \\
\text { Cuspidothrix } \\
\text { issatschenkoi (Usacev } \\
\text { 1938) Rajaniemi et al., } \\
\text { 2005, Oscillatoria sp., } \\
\text { Planktothrix sp., } \\
\text { Chroococcus sp. }\end{array}$ & $\begin{array}{l}\text { 2014: not } \\
\text { available } \\
\text { 2017: Microcystis } \\
\text { aeruginosa, } \\
\text { Microcystis } \\
\text { wesenbergii, } \\
\text { Woronichinia } \\
\text { naegeliana, } \\
\text { Aphanizomenon } \\
\text { sp., Snowella } \mathrm{sp} .\end{array}$ \\
\hline $\begin{array}{l}\text { Cyanobacteria } \\
\text { dominated in } \\
\text { waterbodies and } \\
\text { creating blooms } \\
\text { (cyanobacteria } \\
\text { biomass } \geq 3 \mathrm{mg} \text { / } \\
\text { 1) }\end{array}$ & $\begin{array}{l}\text { 2014: Aphanizomenon } \\
\text { flosaquae } \\
\text { 2017: Microcystis } \\
\text { aeruginosa }\end{array}$ & $\begin{array}{l}\text { 2014: Aphanizomenon } \\
\text { flosaquae } \\
\text { 2017: Microcystis } \\
\text { aeruginosa }\end{array}$ & $\begin{array}{l}\text { 2014: Microcystis } \\
\text { ichthyoblabe, Microcystis } \\
\text { wesenbergii, } \\
\text { Woronichinia naegeliana } \\
\text { 2017: Microcystis } \\
\text { aeruginosa }\end{array}$ & $\begin{array}{l}\text { 2014: not } \\
\text { available } \\
\text { 2017: Microcystis } \\
\text { aeruginosa, } \\
\text { Microcystis } \\
\text { wesenbergii }\end{array}$ \\
\hline
\end{tabular}


employed a Nikon H550L light microscope at $\times 40$ $\times 1000$.

Ciliates were divided into feeding guilds (Hopkins et al. 1993; definition of guilds in Stroud et al., 2015) based on trophic groups separated in Kosiba et al. (2017) as: algivorous ciliates, bacterivorous ciliates and mixed-feeding ciliates (algae and bacteria; Kosiba et al., 2017; Krztoń \& Kosiba, 2020; Table 2).

\section{Statistical analysis}

GLM was used for testing the relationship between total biomass of predatory copepods and total biomass of ciliates. Further, we analysed differences in biomass of predatory copepods and biomass of guilds of ciliates between the periods with and without bloom. Counts were expressed as median values, with 25 th and 75 th percentiles in a box plot diagram. Next, we also used a generalized linear model (GLM) to test the model of the relationship between the biomass of predatory copepods and feeding guilds of ciliates: (a) algivorous ciliates, (b) bacterivorous ciliates, (c) mixed-feeding (algae and bacterivorous) ciliates. Analyses were done for periods with and without blooms and also tested the alone effect of cyanobacterial bloom on the biomass of predatory metazoans. Next, we tested the interaction how the bloom affects the relationship between predatory metazoans and their prey. All statistical analyses were performed by means of R-studio, R v. 4.0.2 (R Core Team, 2020).

\section{Results}

We found cyanobacterial blooms in all four waterbodies. The length of duration of these phenomena was different in each waterbody, however, the shortest lasted 1 month and the longest 5 months. Altogether, we collected 101 samples: 31 samples during a cyanobacterial bloom, and 70 samples in the periods without cyanobacterial blooms. 18 species of ciliates and 10 species of predatory metazooplankton (copepods) were identified in the study material. Amongst predatory copepods the following species were present: Acanthocyclops robustus Sars, 1863, Acanthocyclops trajani Mirabdullayev \& Defaye, 2004, Acanthocyclops venustus Norman \& Scott, 1906, Cyclops abyssorum Sars, 1863, Cyclops strenuus Sars,

Table 2 Chosen feeding guilds of protozooplankton

\begin{tabular}{|c|c|c|}
\hline Feeding guilds & Species & Lifestyle \\
\hline \multirow[t]{3}{*}{ Algivorous ciliates } & Codonella cratera Leidy, 1887 & Free-swimming \\
\hline & Coleps spetai Foissner, 1984 & Free-swimming \\
\hline & Tintinidium sp. & Free-swimming \\
\hline \multirow[t]{8}{*}{ Bacterivorous ciliates } & Aspidisca $\mathrm{sp}$. & Crawling \\
\hline & Epistylis sp. & Sedentary \\
\hline & Non-identified ciliate & Free-swimming \\
\hline & Small scuticociliata & Free-swimming \\
\hline & Tetrahymena sp. & Free-swimming \\
\hline & Vorticella convallaria Linnaeus, 1758 & Sedentary \\
\hline & Vorticella sp. & Sedentary \\
\hline & Opercularia sp. & Sedentary \\
\hline \multirow[t]{7}{*}{ Mixed feeding (algae and bacteria) ciliates } & Coleps hirtus (Müller, 1786) Nitzsch, 1827 & Free-swimming \\
\hline & Frontonia sp. & Free-swimming \\
\hline & Holophrya sp. & Free-swimming \\
\hline & Paramecium sp. & Free-swimming \\
\hline & Stentor sp. & Free-swimming \\
\hline & Strobilidium sp. & Free-swimming \\
\hline & Strombidium sp. & Free-swimming \\
\hline
\end{tabular}


1903, Cyclops vicinus Uljanin, 1875, Mesocyclops leuckarti Claus, 1857, Thermocyclops crassus Fischer, 1853, Thermocyclops dybowskii Landé, 1890 and Thermocyclops oithonoides Sars, 1863. The species of ciliates divided into feeding guilds were presented in Table 2.

The total biomass of predatory copepods was positively linked to the total biomass of ciliates, both, during bloom periods $(P=0.0168)$ and in non-bloom periods $(P=0.0961)$. However, further analyses did not show statistically significant differences between the biomass of any groups of planktonic animals (bacterivorous ciliates, algivorous ciliates, mixed type feeding ciliates, predatory copepods) in the periods without and with blooms (Fig. 1).

Statistical analysis (GLM) showed a positive significant effect of the biomass of two feeding guilds: (1) algivorous ciliates $(P=0.029)$ and $(2)$ bacteri-algivorous ciliates $(P=0.023)$ on the biomass of predatory copepods, during periods without cyanobacterial blooms (Table 3). For the cyanobacterial bloom effect alone, we did not find a significant relationship with predatory metazoans biomass. For algivorous and mixed-feeding ciliates (in interaction with present of cyanobacterial bloom) the bloom enhanced the relationship with predators (as evidenced by the increase in estimate for the groups tested). In contrast, no statistically significant effect of the biomass of bacterivorous ciliates on the biomass of predatory copepods was noted, either during periods of bloom or periods without bloom, either in interaction (Table 3).

\section{Discussion}

The role of ciliated protozoans in fluxing primary production during cyanobacterial blooms has been already indicated, however, this topic is still understudied and it is not fully understood (Ger et al., 2016). Ciliates are an important component of the 'microbial loop', transferring matter and energy during cyanobacterial blooms from bacteria to metazooplankton predators (Johnke et al., 2017) and therefore contributing to the biogeochemical cycling of nutrients (Berman et al., 1987). Feeding the bacteria and algae (Gaedke et al., 2002; Engström-Öst et al., 2013) protozooplankton transfers the carbon to metazoans. Ciliates may be grazed upon by predatory metazoans (Gifford, 1991; Wickham, 1995), which may have essential importance during cyanobacterial bloom periods (Ger et al., 2016).

Predatory metazooplankton are able to reduce the abundance of ciliate communities and depend on the potential of reproduction and the mortality rate of ciliates which are imposed by the predators (Gilbert \& Jack, 1993; Wiąckowski et al., 1994b). Wickham \& Gilbert (1991, 1993) showed that metazooplankton suppress ciliates through predation and mutual competition and that ciliates are an important source of nutrients and may thus facilitate utilization of organic carbon by predatory metazooplankton (Stoecker \& Capuzzo, 1990). Since eutrophication tends to strengthen coupling between protozooplankton and metazooplankton (Ger et al., 2016), we expected to find a significant relationship between the total biomass of ciliates and the total biomass of predatory metazooplankton (copepods) during cyanobacterial blooms. Meanwhile, the results of our studies demonstrated a significant relationship between both groups during both periods (bloom and non-bloom). This demonstrates that the ciliate-copepod link is important for aquatic ecosystems, independently of bloom occurrence conditions.

Therefore, we have taken a deeper look into the ciliate-copepod link, with emphasis on the feeding preferences of ciliates (feeding guilds). We expected a special importance of bacterivorous ciliates, considering a study by Christoffersen et al. (1990), who found that ciliates under a body size of $50 \mu \mathrm{m}$ removed 19-39\% of bacterial production. Therefore, we expected that differences in biomass of bacterivorous ciliates would be significantly higher in the bloom period in comparison with the non-bloom period. However, our results did not support our thesis. Moreover, the biomass of other ciliate guilds (algivorous and bacteri-algivorous type feeding) and predatory copepods did not demonstrate statistically significant differences between periods with and without bloom. Furthermore, we did not find any statistically significant effect of total biomass of ciliates on predatory copepod biomass, independently of bloom or non-bloom periods. However, we found such a positive effect for the biomass of algivorous and mixed type feeding ciliates on predatory copepod biomass. Therefore, we decided to include interactions in the GLM analyses to test how the bloom affects the relationship between predatory metazoans and their prey. During the bloom periods, this effect was 
(a)

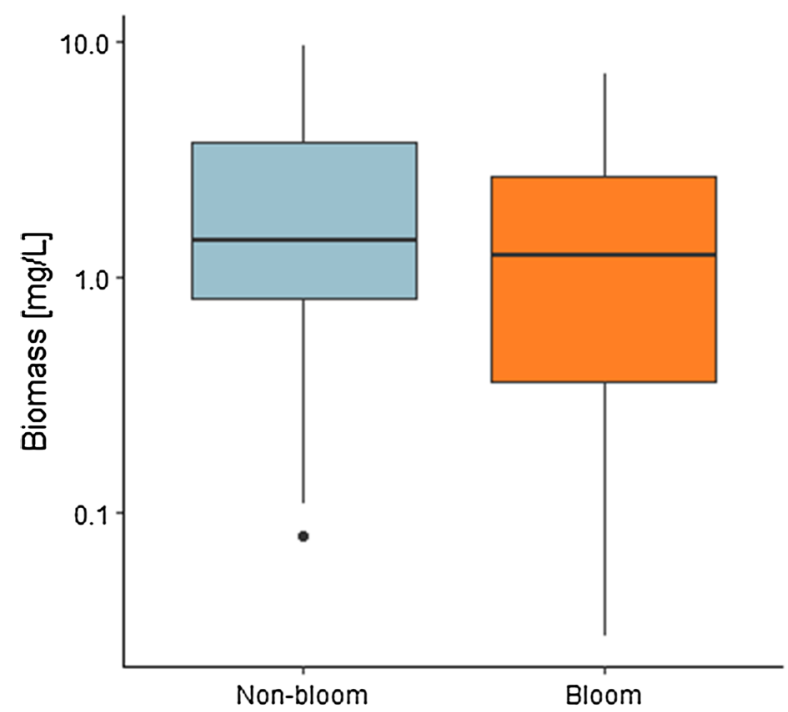

(c)

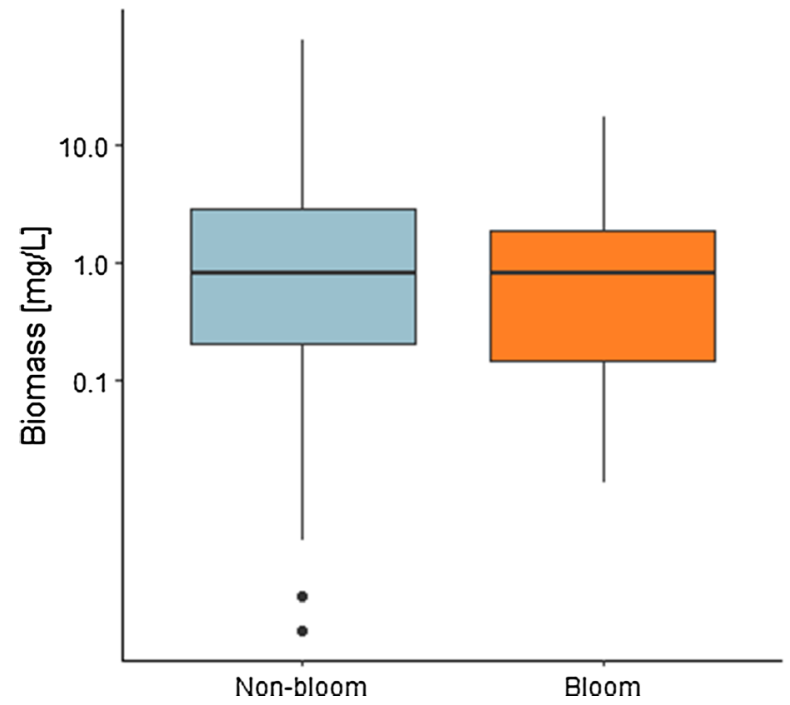

Fig. 1 Box plots for periods without and with cyanobacterial bloom for a predatory copepods, b algivorous ciliates, c bacterivorous ciliates, $\mathbf{d}$ mixed-feeding (algae and bacterivorous) ciliates. The horizontal lines represent the median, the boxes represent 1 st and 3rd percentiles, the vertical lines

stronger compared to non-bloom periods. It seems that the bloom enhanced the relationship between prey and predator. We believe that the copepods showed little interest in the small bacterivorous ciliates when they had access to a better food source in the form of larger species of ciliates from other guilds (mixed feeding and algivorous). It appears that the size of the ciliate, (b)

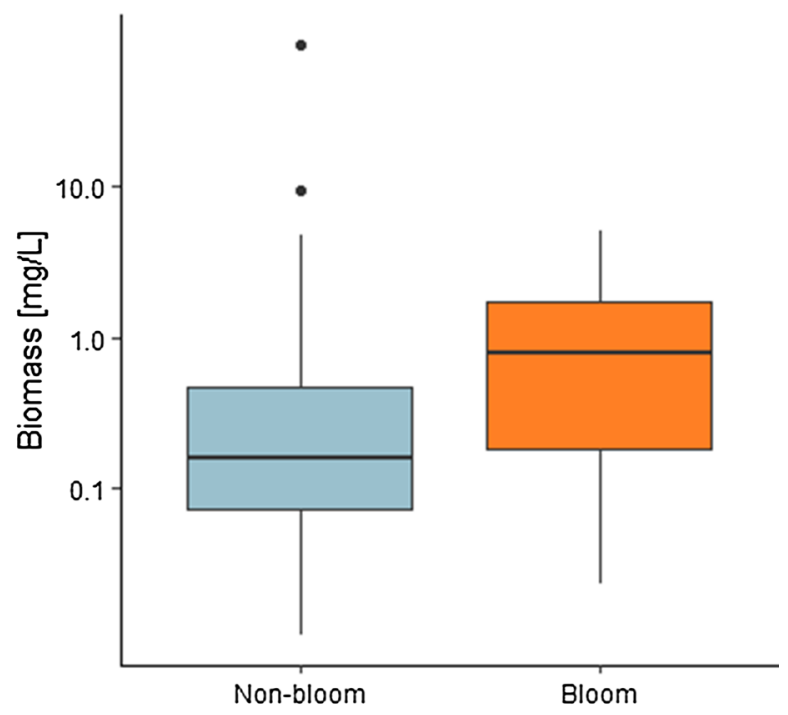

(d)

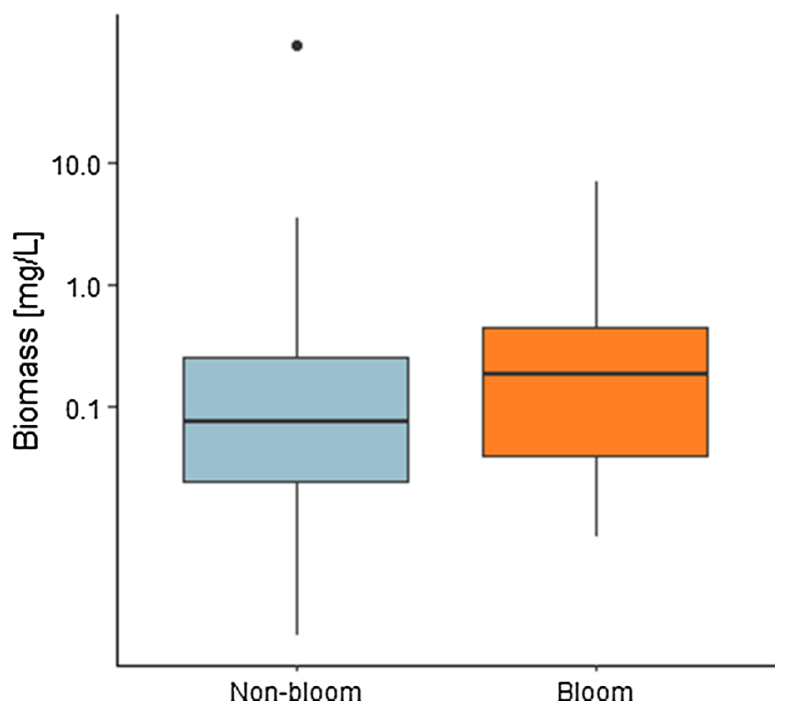

represent range, and the points represent outliers. The blue boxes represent the values of each group for the period without cyanobacterial bloom, the orange boxes represent the values for the period with cyanobacterial bloom

as a food unit, is of considerable significance. In studies to date, all species of zooplankton have showed the highest preferences for grazing for ciliates in the size range of $20-55 \mu \mathrm{m}$ (Adrian \& Schneider-Olt, 1999). In our studies, algivorous and bacteri-algivorous ciliates consisted of bigger species $(35-100 \mu \mathrm{m})$, whereas bacterivorous were of a smaller size 
Table 3 The effect of the biomass of individual feeding guilds of ciliates during periods of cyanobacterial bloom and periods without bloom on the biomass of predatory metazooplankton (copepods)

\begin{tabular}{|c|c|c|c|c|c|}
\hline Predictor & Effects & Estimate & Std error & $t$ value & $P(>|\mathrm{t}|)$ \\
\hline \multirow[t]{4}{*}{ Algivorous ciliates } & Intercept & 1.867 & 0.262 & 7.115 & $<0.001$ \\
\hline & Biomass of ciliates (without bloom) & 0.055 & 0.025 & 2.221 & 0.029 \\
\hline & Cyano bloom & -0.578 & 0.555 & -1.042 & 0.300 \\
\hline & Biomass: cyano bloom & 0.490 & 0.295 & 1.662 & 0.099 \\
\hline \multirow[t]{4}{*}{ Bacterivorous ciliates } & Intercept & 2.030 & 0.277 & 7.324 & $<0.001$ \\
\hline & Biomass of ciliates (without bloom) & -0.020 & 0.025 & -0.816 & 0.417 \\
\hline & Cyano bloom & -0.428 & 0.519 & -0.824 & 0.412 \\
\hline & Biomass: cyano bloom & 0.165 & 0.114 & 1.453 & 0.150 \\
\hline \multirow[t]{4}{*}{ Mixed (algae and bacteria) feeding ciliates } & Intercept & 1.880 & 0.259 & 7.254 & $<0.001$ \\
\hline & Biomass of ciliates (without bloom) & 0.054 & 0.023 & 2.311 & 0.023 \\
\hline & Cyano bloom & -0.372 & 0.489 & -0.760 & 0.449 \\
\hline & Biomass: cyano bloom & 0.460 & 0.238 & 1.934 & 0.056 \\
\hline
\end{tabular}

In table are groups of ciliates tested with predatory metazooplankton; statistical significance are emboldened

$(20-60 \mu \mathrm{m})$. Therefore, the predatory metazooplankton preferred ciliates not belonging to the bacterivorous guild as a food source, which explains the relationships observed by us. Of importance in grazing preferences may also be the capacity for movement, which up until now has been seen as a better life strategy for avoiding predators (Bray, 2001). The mechanism of prey capture (Kiørboe, 2011) of metazoan predators included in our study (cyclopoid copepods) is ambush feeding. Therefore, we explain our results from the perspective of the possibility of prey detection. Hydrodynamic disturbances allow predators to detect motile prey and then rapidly jump. Studies conducted to date have suggested that ciliates may weaken the predatory behaviour of metazooplankton by actively fleeing (Gilbert \& Jack, 1993; Gilbert, 1994; Burns \& Gilbert, 1993; Broglio et al., 2001). However, the results of our study may demonstrate the reverse.

We compared the way of moving (do they swim or not-Table 2; Lisicki et al., 2019) and the type of food (bacterivorous, algivorous, mixed type of feeding) of chosen species of ciliates. We found that algivorous and mixed type feeding ciliates are free-swimming species, but the majority of bacterivorous ciliates are sedentary (Epistylis sp., Opercularia sp., Vorticella convallaria Linnaeus, 1758 and Vorticella sp.). However, some of bacterivorous ciliates may also graze whilst swimming on bacteria formed on organic matter. Species belonging to algi- and bacteri-algivorous (mixed type feeding) guilds moved through the water column relatively quickly, making them easy to recognize by the ambush feeding predatory copepods. The ability to recognize prey due to water movements generated by this prey is all the more significant when the aquatic environment is of low visibility, a characteristic feature during periods of cyanobacterial bloom. The actively grazing copepods are thus quite able to feed themselves in environments of low water visibility by sensing motion in the water.

Therefore, larger body size and the ability to move quickly paradoxically may not be the best strategy for predator avoidance. According to Kiørboe \& Visser (1999), larger copepods usually select larger prey, because they make stronger disturbances in the water, so they are easier to perceive and to be caught by the copepods, which use mechanoreceptors to detect their prey. Wiąckowski et al. (1994b) have similar observations on larger ciliates, which were more often attacked by adult predatory copepods. Usually, predatory copepods behave in ways predicted by the optimal foraging theory and select prey that maximize their trophic benefit (Wiackowski \& Kocerba-Soroka, 2017). In a system such as the one we studied, the ability to move actively may be a worse survival strategy than sedentary foraging, as it generates motion in the water which informs predators of the presence of prey and requires greater energy inputs. 
Our results suggest that the ciliate-predatory copepod link in eutrophic aquatic ecosystems is a significant pathway of energy flow, functioning both under non-bloom and bloom periods. The relationship of predatory copepod biomass with algivorous and bacteri-algivorous ciliates biomasses, with a simultaneous lack of relationship with bacterivorous ciliate biomass, suggests that bacterial fixed carbon may be only partially contributing the total energy passed through this link. An important factor controlling this process might be the life strategies and behaviour of ciliates. Larger and free-swimming ciliate species appear to play a greater role in energy transfer than smaller and sedentary species. Further more detailed information on the mutual relationship between ciliates and predatory copepods may be provided by study involving stable isotopes.

\section{Conclusion}

Hypothesis 1 was not confirmed by this study as there was a significant relationship between ciliate and copepod biomasses both under bloom conditions and in periods without blooms. Hypothesis 2 was not confirmed by this study as individual guilds of ciliate biomass did not display statistically significant differences between the two periods (bloom/non-bloom). Hypothesis 3 and our expectations were partially confirmed by the study. The biomass of bacterivorous ciliates did not significantly affect the biomass of predatory copepods. The biomass of algivorous ciliates affected the biomass of predatory copepods in both periods (bloom/non-bloom), though this effect was stronger in the bloom period than in the period without bloom. The biomass of mixed-feeding bacterialgivorous ciliates had a significant effect on the biomass of predatory copepods in both periods, but also stronger during the bloom. This proves that the bloom enhanced the relationship between prey and predator. The results suggested that the larger, more mobile ciliates (primarily those from the algivorous and bacteri-algivorous guilds) are preyed upon by copepods, whilst smaller, more sedentary ciliates (primarily bacterivorous) most likely constitute a less desirable food source for predatory copepods.

Acknowledgements We thank Dr. Edward Walusiak for assistance with sampling as well as Prof. Elżbieta Wilk-
Woźniak for their valuable and constructive suggestions during the development of this work. We would also like to thank anonymous reviewers and Editor for sharing your doubts and valuable comments and suggestions.

Funding This study was supported by the Institute of Nature Conservation, Polish Academy of Sciences, through its statutory fund and a grant for young scientists and Ph.D. candidates, for the PhD students: Joanna Kosiba and Wojciech Krzton.

\section{Declarations}

Conflict of interest The authors declare that they have no conflicts of interest.

Open Access This article is licensed under a Creative Commons Attribution 4.0 International License, which permits use, sharing, adaptation, distribution and reproduction in any medium or format, as long as you give appropriate credit to the original author(s) and the source, provide a link to the Creative Commons licence, and indicate if changes were made. The images or other third party material in this article are included in the article's Creative Commons licence, unless indicated otherwise in a credit line to the material. If material is not included in the article's Creative Commons licence and your intended use is not permitted by statutory regulation or exceeds the permitted use, you will need to obtain permission directly from the copyright holder. To view a copy of this licence, visit http://creativecommons.org/licenses/by/4.0/.

\section{References}

Adrian, R. \& B. Schneider-Olt, 1999. Top-down effects of crustacean zooplankton on pelagic microorganisms in a mesotrophic lake. Journal of Plankton Research 21(11): 2175-2190.

Agasild, H., P. Zingel, K. Karus, K. Kangro, J. Salujoe \& T. Noges, 2013. Does metazooplankton regulate the ciliate community in a shallow eutrophic lake? Freshwater Biology 58(1): 183-191.

Archbold, J. H. G. \& J. Berger, 1985. A qualitative assessment of some metazoan predators of Halteria gradinella, a common freshwater ciliate. Hydrobiologia 126: 97-102.

Berman, T., M. Nawrocki, G. T. Taylor \& D. M. Karl, 1987. Nutrient flux between bacteria, bacterivorous nano-planktonic protists and algae. Marine Microbial Food Webs 2(2): 69-81.

Błędzki, L. A. \& J. I. Rybak, 2016. Freshwater crustacean zooplankton of Europe: Cladocera \& Copepoda (Calanoida, Cyclopoida) key to species identifcation, with notes on ecology, distribution, methods and introduction to data analysis, Springer, New York:.

Boas, L. D. A. V., M. V. X. Senra, K. Fernandes, A. M. da Anunciação Gomes, R. J. P. Dias, E. Pinto \& A. L. Fonseca, 2020. In vitro toxicity of isolated strains and cyanobacterial bloom biomasses over Paramecium caudatum (ciliophora): Lessons from a non-metazoan model organism. Ecotoxicology and Environmental Safety 202: 110937. 
Bottrell, H. H., A. Duncan, Z. M. Gliwicz, E. Grygierek, A. Herzig, A. Hillbricht-Ilkowska, H. Kurasawa, P. Larsson \& T. Weglenska, 1976. A review of some problems in zooplankton production studies. Norwegian Journal of Zoology 24: 419-456.

Bray, D., 2001. Cell Movements: From Molecules to Motility, Garland Science, New York:

Broglio, E., M. Johansson \& P. R. Jonsson, 2001. Trophic interaction between copepods and ciliates: effects of prey swimming behavior on predation risk. Marine Ecology Progress Series 220: 179-186.

Burns, C. W. \& J. J. Gilbert, 1993. Predation on ciliates by freshwater calanoid copepods: rates of predation and relative vulnerabilities of prey. Freshwater Biology 30: 377-393.

Calbet, A. \& E. Saiz, 2005. The ciliate-copepod link in marine ecosystems. Aquatic Microbial Ecology 38(2): 157-167.

Carlson, R. E. \& J. Simpson, 1996. A Coordinator's Guide to Volunteer Lake Monitoring Methods, North American Lake Management Society, Madison:

Chorus, I., 2001. Cyanotoxins: Occurrence, Causes, SpringerVerlag, Berlin, Consequences:

Christoffersen, K., B. Riemann, L. R. Hansen, A. Klysner \& H. B. Sørensen, 1990. Qualitative importance of the microbial loop and plankton community structure in a eutrophic lake during a bloom of cyanobacteria. Microbial Ecology 20: 253-272.

Codd, G. A., 1995. Cyanobacterial toxins: occurrence, properties and biological significance. Water Science Technology 32: 149-156.

Cummins, K. W., R. R. Costa, R. E. Rowe, G. A. Moshiri, R. M. Scanlon \& R. K. Zajdel, 1969. Ecological energetics of a natural population of the predaceous zooplankter Leptodora kindtii. Oikos 20: 189-223.

Dumont, H. J., I. Van de Velde \& S. Dumont, 1975. The dry weight estimate of biomass in a selection of Cladocera, Copepoda and Rotifera from the plankton, periphyton, and benthos of continental waters. Oecologia (berlin) 19: 75-97.

Ejsmont-Karabin, J., S. Radwan \& I. Bielańska-Grajner, 2004. Rotifers, Monogononta-atlas of species. Polish freshwater fauna. University of Łódź, Łódź:, 77-447.

Elert, E. V., D. Martin-Creuzburg \& J. R. Le Coz, 2003. Absence of sterols constrains carbon transfer between cyanobacteria and a freshwater herbivore (Daphnia galeata). Proceedings of the Royal Society of London B. Biological Sciences 270(1520), 1209-1214.

Engström-Öst, J., R. Autio, O. Setälä, S. Sopanen \& S. Suikkanen, 2013. Plankton community dynamics during decay of a cyanobacteria bloom: a mesocosm experiment. Hydrobiologia 701: 25-35.

Firth, P. \& S. G., Fisher, 2012. Global Climate Change and Freshwater Ecosystems, Springer, Berlin:

Foissner, W. \& H. Berger, 1996. A user-friendly guide to the ciliates (Protozoa, Ciliophora) commonly used by hydrobiologists as bioindicators in rivers, lakes, and waste waters, with notes on their ecology. Freshwater Biology 35(2): 375-482.

Foissner, W. \& H. Berger, 1999. Schaumburg J. Identification and Ecology of Limnetic Plankton Ciliates.
Informationsberichte des Bayer. Landesamtes für Wasserwirtschaft, München.

Gaedke, U., S. Hochstädter \& D. Straile, 2002. Interplay between energy limitation and nutritional deficiency: empirical data and food web models. Ecological Monographs 72(2): 251-270.

Ger, K. A., P. Urrutia-Cordero, P. C. Frost, L. A. Hansson, O. Sarnelle, A. E. Wilson \& M. Lürling, 2016. The interaction between cyanobacteria and zooplankton in a more eutrophic world. Harmful Algae 54: 128-144.

Gifford, D. J., 1991. The protozoan-metazoan trophic link in pelagic ecosystems. Journal of Protozoology 38: 81-86.

Gilbert, J. J., 1994. Jumping behavior in the Oligotrich ciliate Strombilidium velox and Halteria grandinella, and its significance as a defence against rotifer predators. Microbial Ecology 27: 189-200.

Gilbert, J. J. \& J. D. Jack, 1993. Rotifers as predators on small ciliates. Hydrobiologia 255(256): 247-253.

Güher, H., 2002. Cladocera and Copepoda (Crustacea) Fauna of Lake Terkos (Durusu). Turkish Journal of Zoology 26(3): 283-288.

Hopkins, T. L., T. M. Lancraft, J. J. Torres \& J. Donnelly, 1993. Community structure and trophic ecology of zooplankton in the scotia sea marginal ice zone in winter (1988). Deep Sea Research Part i: Oceanographic Research Papers 40(1): 81-105.

Huisman, J., G. A. Codd, H. W. Paerl, B. W. Ibelings, J. M. Verspagen \& P. M. Visser, 2018. Cyanobacterial blooms. Nature Reviews Microbiology 16(8): 471-483.

Jack, J. D. \& J. J. Gilbert, 1997. Effects of metazoan predators on ciliates in freshwater Plankton Communities 1. Journal of Eukaryotic Microbiology 44(3): 194-199.

Jeppesen, E., J. P. Jensen, M. Søndergaard, T. Lauridsen, L. J. Pedersen \& L. Jensen, 1997. Top-down control in freshwater lakes: the role of nutrient state, submerged macrophytes and water depth, Shallow Lakes' 95 Springer, Dordrecht: 151-164.

Jerome, C. A., D. J. S. Montagnes \& F. J. R. Taylor, 1993. The effect of the quantitative protargol stain and Lugols and Buinos fixatives on cell size: a more accurate estimate of ciliate species biomass. Journal of Eukaryotic Microbiology 40: 254-259.

Johnke, J., A. Chatzinotas, H. Harms \& J. Boenigk, 2017. Killing the killer: predation between protists and predatory bacteria. FEMS Microbiology Letters 364: fnx089.

Jumars, P. A., D. L. Penry, J. A. Baross, M. J. Perry \& B.W. Frost, 1989. Closing the microbial loop: dissolved carbon pathway to heterotrophic bacteria from incomplete ingestion, digestion and absorption in animals. Deep Sea Research Part A. Oceanographic Research Papers 36(4): 483-495.

Jürgens, K., O. Skibbe \& E. Jeppesen, 1999. Impact of metazooplankton on the composition and population dynamics of planktonic ciliates in a shallow, hypertrophic lake. Aquatic Microbial Ecology 17(1): 61-75.

Kalinowska, K., 2004. Bacteria, nanoflagellates and ciliates as components of the microbial loop in three lakes of different trophic status. Polish Journal of Ecology 1(52).

Kalinowska, K., J. Ejsmont-Karabin, M. Rzepecki, I. Kostrzewska- Szlakowska, I. Y. Feniova, A. Palash \& A. 
R. Dzialowski, 2015. Impacts of large-bodied crustaceans on the microbial loop. Hydrobiologia 744(1): 115-125.

Kiørboe, T., 2011. How zooplankton feed: mechanisms, traits and trade-offs. Biological Reviews 86(2): 311-339.

Kiørboe, T. \& A. W. Visser, 1999. Predator and prey perception in copepods due to hydromechanical signals. Marine Ecology Progress Series 179: 81-95.

Komárek, J., 2013. Cyanoprokaryota, 3. Teil / 3rd part: Heterocytous Genera. Süsswasserflora von Mitteleuropa 19/3, Springer, Berlin.

Komárek, J. \& K. Anagnostidis, 1998. Cyanoprokaryota, 1. Teil: Chroococcales. Süsswasserflora von Mitteleuropa 19/1. Gustav Fischer Verlag, Stuttgart.

Komárek, J. \& K. Anagnostidis, 2005. Cyanoprokaryota, 2. Teil/ 2nd Part: Oscillatoriales. Süsswasserflora von Mitteleuropa 19/2. Elsevier, Spektrum Akademischer Verlag, Heidelberg.

Kosiba, J., E. Wilk-Woźniak, W. Krztoń, M. Strzesak, A. Pociecha, E. Walusiak, K. Pudaś \& E. Szarek-Gwiazda, 2017. What underpins the trophic networks of the plankton in shallow oxbow lakes? Microbial Ecology 73(1): 17-28.

Kosiba, J., E. Wilk-Woźniak \& W. Krztoń, 2018. Effect of Microcystins on Proto- and Metazooplankton is more evident in artificial than in natural waterbodies. Microbial Ecology 75: 293-302.

Krztoń, W. \& J. Kosiba, 2020. Variations in zooplankton functional groups density in freshwater ecosystems exposed to cyanobacterial blooms. Science of the Total Environment. https://doi.org/10.1016/j.scitotenv.2020. 139044.

Krztoń, W., J. Kosiba, A. Pociecha \& E. Wilk-Woźniak, 2019. The effect of cyanobacterial blooms on bio- and functional diversity of zooplankton communities. Biodiversity and Conservation 28(7): 1815-1835.

Laybourn-Parry, J., B. A. Abdullahi \& S. Tinson, 1988. Temperature dependent energy partitioning in the benthic copepods Acanthocyclops viridis and Macrocyclops albidus. Canadian Journal of Zoology 66: 2709-2714.

Lisicki, M., M. F. Velho Rodrigues, R. E. Goldstein \& E. Lauga, 2019. Swimming eukaryotic microorganisms exhibit a universal speed distribution. eLife 8. e44907.

Mantzouki, E., M. Lürling, J. Fastner, L. de Senerpont Domis, E. Wilk-Woźniak \& J. Koreivienè, 2018. Temperature effects explain continental scale distribution of cyanobacterial toxins. Toxins 10(4): 156.

Martins, J., L. Peixe \& V. M. Vasconcelos, 2011. Unraveling cyanobacteria ecology in wastewater treatment plants (WWTP). Microbial Ecology 62(2): 241-256.

Napiórkowska-Krzebietke, A., K. Kalinowska, E. BogackaKapusta, K. Stawecki \& P. Traczuk, 2021. Persistent blooms of filamentous cyanobacteria in a cormorant-affected aquatic ecosystem: Ecological indicators and consequences. Ecological Indicators 124: 107421.

Nebaeus, M., 1984. Algal water-blooms under ice-cover: with 1 figure and 2 tables in the text. Verhandlungen Der Internationalen Vereinigung Fur Theoretische Und Angewandte Limnologie 22(2): 719-724.

Pace, M. L. \& G. Lovett, 2013. Primary production: the foundation of ecosystems. In Weathers, K. C., D. L. Strayer \& G. E. Likens (eds), Fundamentals of ecosystem science 2nd ed. Elsevier Academic Press, London: 27-51.
Paerl, H. W. \& J. Huisman, 2009. Climate change: a catalyst for global expansion of harmful cyanobacterial blooms. Environmental Microbiology Reports 1(1): 27-37.

Pagels, F., V. Vasconcelos \& A. C. Guedes, 2021. Carotenoids from Cyanobacteria: Biotechnological Potential and Optimization Strategies. Biomolecules 11(5): 735.

Paldavičiene, A., A. Zaiko, H. Mazur-Marzec \& A. RazinkovasBaziukas, 2015. Bioaccumulation of microcystins in invasive bivalves: a case study from the boreal lagoon ecosystem. Oceanologia 57(1): 93-101.

Papadimitriou, T., I. Kagalou, V. Bacopoulos \& I. D. Leonardos, 2010. Accumulation of microcystins in water and fish tissues: an estimation of risks associated with microcystins in most of the Greek Lakes. Environmental Toxicology 25(4): 418-427.

Pearsson, G. \& G. Ekbohm, 1980. Estimation of dry-weight in zooplankton populations-methods applied to crustacean populations from lakes in the Kuokkel Area. Northern Sweden. Archiv Für Hydrobiologie. 89: 225-246.

Porter, K. G., M. L. Pace \& J. F. Battey, 1979. Ciliate protozoans as links in freshwater planktonic food chains. Nature 277(5697): 563-565.

Puharinen, S. T., 2021. Good Status in the Changing Climate?Climate Proofing Law on Water Management in the EU. Sustainability 13(2): 517.

Putt, M. \& D. K. Stoecker, 1989. An experimentally determined carbon: volume ratio for marine "oligotrichous" ciliates from estuarine and coastal waters. Limnology and Oceanography 34: 1097-1103.

R Core Team, 2020. R: A Language and Environment for Statistical Computing, R Foundation for Statistical Computing, Vienna:

Rott, E., 1981. Some results from phytoplankton counting intercalibrations. Schweizerische Zeitschrift Fur Hydrologie 43: 34-62.

Ruttner-Kolisko, A., 1977. Suggestions for biomass calculation of plankton rotifers. Archiv für Hydrobiologie. Beihefte, Ergebnisse der Limnologie 8(7): 1-76.

Sanders, R. W. \& S. A. Wickham, 1993. Planktonic protozoa and metazoa: predation, food quality and population control. Marine Microbial Food Webs 7: 197-223.

Sherr, E. B. \& B. F. Sherr, 2002. Significance of predation by protists in aquatic microbial food webs. Antonie Van Leeuwenhoek International Journal of General and Molecular Microbiology 81: 293-308.

Sherr, E. B. \& B. F. Sherr, 2007. Heterotrophic dinoflagellates: a significant component of microzooplankton biomass and major grazers of diatoms in the sea. Marine Ecology Progress Series 352: 187-197.

Sommer, U., R. Adrian, L. De Senerpont Domis, J. J. Elser, U. Gaedke, B. Ibelings, E. Jeppesen, M. Lürling, J. C. Molinero, W. M. E. Mooij \& E. Van Donk, 2012. Beyond the plankton ecology group (PEG) model: Mechanisms driving plankton succession. Annual Review of Ecology Evolution and Systematics 43: 429-448. https://doi.org/10.1146/ ANNUREV-ECOLSYS-110411-160251.

Stoecker, D. K. \& J. M. Capuzzo, 1990. Predation on protozoa: its importance to zooplankton. Journal of Plankton Research 12: 891-908.

Stroud, J. T., M. R. Bush, M. C. Ladd, R. J. Nowicki, A. A. Shantz \& J. Sweatman, 2015. Is a community still a 
community? Reviewing definitions of key terms in community ecology. Ecology and Evolution 5(21): 4757-4765.

Warren, A., G. F. Esteban \& B. J. Finlay, 2016. Chapter 2Protozoa. In Thorp J. H. \& D. C. Rogers (eds), Thorp and Covich's Freshwater Invertebrates (Fourth Edition), Academic Press, Cambridge: 5-37. https://doi.org/10.1016/ B978-0-12-385028-7.00002-0.

Weisse, T., H. Müller, R. M. Pinto-Coelho, A. Schweizer, D. Springmann \& G. Baldringer, 1990. Response of the microbial loop to the phytoplankton spring bloom in a large prealpine lake. Limnology and Oceanography 35: 781-794.

Wiąckowski, K. \& W. Kocerba-Soroka, 2017. Selective predation by a harpacticoid copepod on ciliates in phytotelmata: a laboratory experiment. Hydrobiologia 790: 13-22.

Wiąckowski, K., A. Doniec \& J. Fyda, 1994a. An empirical study of the effect of fixation on ciliate cell volume. Marine Microbial Food Webs 8(1-2): 59-69.

Wiąckowski, K., M. T. Brett \& C. R. Goldman, 1994b. Differential effects of zooplankton species on ciliate community structure. Limnology and Oceanography 39: 486-492.

Wickham, S. A., 1995. Trophic relations between cyclopoid copepods and ciliated protists: complex interactions link the microbial and classic food webs. Limnology and Oceanography 40(6): 1173-1181.

Wickham, S. A. \& J. J. Gilbert, 1991. Relative vulnerabilities of natural rotifer and ciliate communities to cladocerans: laboratory and field experiments. Freshwater Biology 26(1): 77-86.
Wickham, S. A. \& J. J. Gilbert, 1993. The comparative importance of competition and predation by Daphnia on ciliated protists. Archiv Für Hydrobiologie 126(3): 289-313.

Wilk-Woźniak, E., 2009. Zmiany populacyjne w zbiorowiskach glonów planktonowych oraz ich strategie życiowe w warunkach ekosystemów wodnych sztucznie zmienionych (Changes in phytoplankton communities and the life strategies of planktonic algae in artificially changed aquatic ecosystems). Studia Naturae 55: 1-132 (in Polish).

Wilk-Woźniak, E., 2020. An introduction to the 'micronet'of cyanobacterial harmful algal blooms (CyanoHABs): cyanobacteria, zooplankton and microorganisms: a review. Marine and Freshwater Research 71(5): 636-643.

Wilson, A. E., O. Sarnelle \& A. R. Tillmanns, 2006. Effects of cyanobacterial toxicity and morphology on the population growth of freshwater zooplankton: meta-analyses of laboratory experiments. Limnology and Oceanography 51(4): 1915-1924.

Zingel, P., H. Agasild, T. Nõges \& V. Kisand, 2007. Ciliates are the dominant grazers on pico- and nanoplankton in a shallow, naturally highly eutrophic lake. Microbial Ecology 53: 134-142.

Publisher's Note Springer Nature remains neutral with regard to jurisdictional claims in published maps and institutional affiliations. 